\title{
BIOETHICAL PROBLEMS ARISING IN THE STUDY OF SINGLE- NUCLEOTIDE GENE POLYMORPHISMS OF OCCUPATIONAL DISEASES
}

DOI: 10.36740/WLek202001135

\author{
Tetyana A. Andrushchenko', Sergiy V. Goncharov ${ }^{2}$, Victor E. Dosenko ${ }^{2}$, Konstantin E. Ishhejkin ${ }^{3}$ \\ 'STATE INSTITUTION «KUNDIIEV INSTITUTE OF OCCUPATIONAL HEALTH OF THE NATIONAL ACADEMY OF MEDICAL SCIENCES OF UKRAINE», KYIV, UKRAINE \\ 2DEPARTMENT OF GENERAL AND MOLECULAR PATHOPHYSIOLOGY OF BOGOMOLETS INSTITUTE OF PHYSIOLOGY \\ OF THE NATIONAL ACADEMY OF SCIENCES OF UKRAINE, KYIV, UKRAINE \\ ${ }^{3}$ UKRAINIAN MEDICAL STOMATOLOGICAL ACADEMY, POLTAVA, UKRAINE
}

\begin{abstract}
In Ukraine, about 3 million people work in hazardous and dangerous conditions. The study of hereditary specificity in development of occupational diseases is being actively conducted through molecular genetic analysis of single-nucleotide gene polymorphisms. While studying single-nucleotide gene polymorphisms of occupational diseases, many complicated bioethical questions arise regarding the confidentiality of personal data, the choice between the profession chosen and the risk to one's own health. Complicated bioethical issues that arise when studying single-nucleotide gene polymorphisms of occupational diseases need to be actively discussed, not only by physicians, occupational pathologists, employers, scientists, but also by politicians and lawyers, taking into account ethical and social norms and implications.
\end{abstract}

KEY WORDS: single-nucleotide gene polymorphism; occupational diseases; multifactorial diseases; bioethical issues

Wiad Lek. 2020;73(1)188-190

\section{INTRODUCTION}

In the current state of the industry in Ukraine, the adverse effect of harmful and dangerous production factors on workers in all industries is increasing. The number of productions that do not meet the established standards of the working conditions makes up 35,0-57,7\%. The main reasons for such situation are the aging of production facilities, use of outdated technologies and equipment, inadequate use of collective and personal protection [1]. Occupational diseases is a significant medical and social problem because they are one of important indicators of the health of the working population and can be result of the direct impact of harmful production factors and the labor process on the human body [2]. About 3 million people work in unfavorable conditions in Ukraine.

Recently, the attention of scientists is focused on determining the role of the genetic component in the development of multifactorial diseases (MFD), the category of which includes occupational diseases. Occupational diseases is a group of diseases that are complicated by working conditions, and their frequency exceeds that of workers outside the influence of certain occupational harmful factors. Characteristic features of this group of diseases are: high rates of increase in the incidence, disability and mortality of the working age population, as well as significant economic losses in the form of compensation for disability and disability payments. In Ukraine, the list of occupational diseases was approved by the Decree of the Cabinet of Ministers of Ukraine No. 1662 of November 8, 2000, in which the diseases are presented depending the origin of the production factor. In the list of occupational diseases the following nosological types are presented: chronic bronchitis, pneumosclerosis, fibrotic alveolitis, toxic hepatitis, liver damages with development of fibrosis and cirrhosis, osteoporosis, osteosclerosis, diseases associated with the effect of ionizing and others.

MFD is the most common group of human somatic pathology, their frequency is up to $90 \%$. In the pathogenesis of MFD, several genes play a role, realizing pathological effects only under certain adverse environmental conditions. Modern concepts about etiology of most work-related diseases also include provisions on multifactoriality and polygenicity. It is believed that the risk of occupational diseases depends on the individual susceptibility of humans, which is genetically determined by gene polymorphism [3-6]. However, to date, the role of various occupational factors and gene polymorphisms as those that or change the frequency and course of occupationally induced MFD has not been fully elucidated [3, 7].

\section{THE AIM}

The purpose of the work was to identify the most relevant bioethical issues that occur in the study of single-nucleotide gene polymorphisms of occupational diseases.

\section{REVIEW AND DISCUSSION}

In Ukraine, it was Academician Yuriy Kundiev who began to study the individual susceptibility of persons from 
different occupational groups to the risk of developing occupational diseases using molecular genetic methods, and who was the founder and leader of the bioethical movement in Ukraine (Fig. 1).

Currently, molecular genetic markers are the latest tool for epidemiological research in occupational medicine, they are a real basis for identifying occupational groups of individuals with an increased degree of susceptibility to a specific causing disease or harmful production factor. Genetic factors cannot be modified, so researchers have the unique opportunity to study individual differences of the working body associated with a predisposition to certain occupational factors or occupational diseases. At the same time, workers engaged in hazardous and harmful industries are a specific risk group that is exposed to a double stress, from the effects of adverse working conditions and from the environmental pollution [6]. Several approaches are used to estimate the rate of growth of the mutation process and the volume of genetic load in a population of people who have been affected by adverse factors, including professional ones: - phenotype analysis - studies on the frequency of hereditary diseases, congenital malformations and reproductive function;

- cytogenetic analysis (FISH - fluorescence in situ hybridization) studies on the frequency of unstable and stable chromosomal aberrations, aneuploidy and sister chromatid exchange in human somatic cells;

- molecular genetic analysis - studing gene mutations gene polymorphisms (SNP - Single nucleotide polymorphism) in somatic cells. SNP is the heterogeneity of the primary DNA structure manifested in single-nucleotide (point) differences of alleles [8].

All scientific studies of the human hereditary material involve obtaining the informed consent from each study participant. The informed consent form is developed for the specific study separately and approved by the Bioethics Commission at the venue. The questionnaire provides an explanation for a patient about the purpose and scope of the study, benefit to the patient, and potential risks involved in sampling the biological material. A prerequisite is the confidentiality of the information received. After communication between the researcher and the patient, in the case of the voluntary consent of the latter, a questionnaire should be signed in the presence of a third disinterested person, who also signs the questionnaire.

The sampling of the biological material is made in the manipulation room to a special laboratory vessel, which is marked by the staff, and the patient's surname and initials are encoded by the envisaged coding of the study in order to preserve confidentiality. Further, only the sample number and the study code are used.

Ethically complicated issues arising in the study of single-nucleotide gene polymorphisms of work-related diseases distinguish the ethics of medical genetics from some other sections of bioethics. What are the most frequently asked questions during our research?

- how to properly diagnose a work-related disease, so that only a patient should be aware of the results and could not

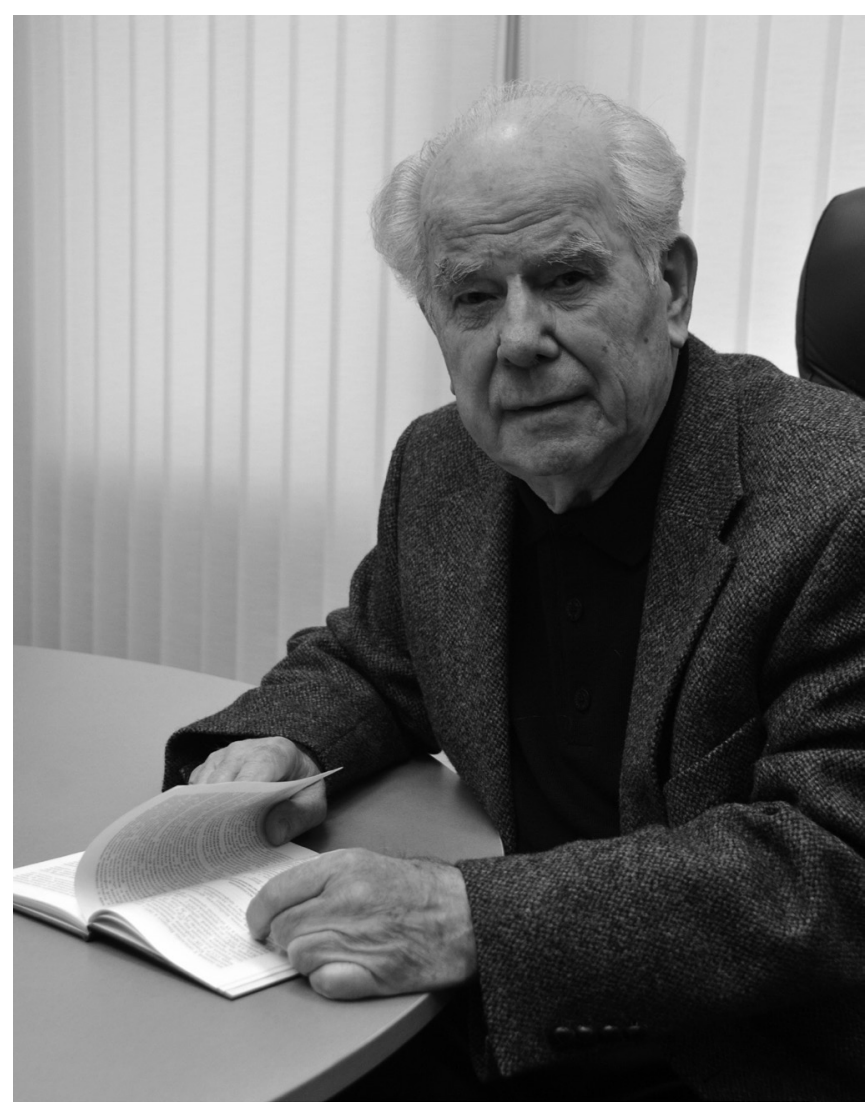

Fig. 1. Leader and founder of the bioethical movement in Ukraine, Academician Yuriy Kundiiev.

disseminate the information himself (to another research participant or employer)?

- what if a work-related illness is already o its late stages and its reverse development is not possible, and it is found that a patient has an individual high risk of developing is disease?

- how to properly work with the biological material: isolate, study, transform, etc.?

- how to use genetic information: store, transfer, distribute, destroy?

In 1997, at the 29th session of UNESCO, the "Universal Declaration on Genome and Human Rights" was adopted. Among its basic tenets of ethical principles of medical genetics our attention was focused on the following principles: - consent to participate in medical-genetic procedures, testing and treatment;

- respect for a person's personality, regardless the level of his/her knowledge;

close cooperation with organizations that unite patients and their relatives;

- use of understandable accessible language when communicating with a patient;

- constant monitoring of the quality of genetic services and procedures;

prevention of discrimination in employment with insurance or training based on genetic information. Among the ethical principles of medical genetics, the latter deserves special attention. It states that the results of sin- 
gle-nucleotide gene polymorphisms associated with the risk of developing an occupational disease should in no case be made known to an employer or other interested person, but only to the patient. If a patient is found to have an individual inherited tendency associated with an increased risk of developing a certain MFD, then he or she should be informed of the risks involved and should not be restricted in his or her choice of profession. If a person is only about to enter a profession with hazardous and dangerous working conditions, then he or she should be provided with comprehensive information about the high risks of certain occupational diseases associated with his or her future employment. What if a patient already has a certain length of service in harmful working conditions and at the same time it is found out that at the same time he has an individual high risk of developing a certain work-related MFD? The answer is one... only compelling medical advice and clarification in a readily available language about medical contraindications, high risks of developing MFD that are individually determined with the patient's voluntary consent. An explanation of rational employment is also needed to allow the patient to prolong duration and quality of life.

\section{CONCLUSIONS}

Therefore, single-nucleotide gene polymorphisms are latent life-long risk factors that can be developed under conditions of exposure to harmful environmental factors to a pathological process. Genetic factors cannot be modified, and there is a unique opportunity to use fundamentally new ways of preventing occupational MFD based on the consideration of individual inherited-related characteristics of the working person. Mass genotyping and formation of risk groups in occupational groups with subsequent survey, based on individual genetic predisposition is a cost-effective method of preventing work-related diseases. Complicated bioethical issues that arise when studying single-nucleotide gene polymorphisms of occupational diseases need to be actively discussed, not only by physicians, occupational pathologists, employers, scientists, but also by politicians and lawyers, taking into account ethical and social norms and implications.

\section{REFERENCES}

1. Kundiev YI. Medicina truda - pyatidesyatiletniy opit [Fifty years of experience in occupational medicine]. Kiev. Avicenna Publishing House. 2002; 496-511. (in Ukrainian).

2. Korobchansky VA. Medicina pogranichnih sostoyaniy: focus na professionalnie zabolevaniya [Borderline medicine: a focus on occupational diseases]. Ukrainian medical journal. 2018; 5 (127):27-29. (in Ukrainian).

3. Kuzmina LP. Genomika I proteomika v medicine truda [Genomics and Proteomics in Occupational Health Research]. Medical and ecological problems of health of workers. 2004; 2: 25-30. (in Russian).
4. Polonikov AV. Polymorphism genov fermentov biotransformacii ksenobiotokov i ih kompleksnoe vliyanie na predraspplozheno $\mathrm{k}$ multifactorialnim zabolevaniyam [Polymorphism of xenobiotic biotransformation enzyme genes and their complex influence on the predisposition to multifactorial diseases]: author. diss. for the sciences. degree doct. honey. Sciences. Genetics. Moscow. 2006; 1-14. (in Russian).

5. Baranov VS. Genom cheloveka "nedostaushchaya" nasledstvennost I geneticheskiy passport [Human genome «missing» heredity and genetic passport]. Med. Genetics. 2011; 9: 3-10. (in Russian).

6. Izmerov NF, Chuchalin AG. Profesionalnie bolezni organov dihaniya [Occupational diseases of the respiratory system]. Moscow. Publish in group "GEOTAR-Media". 2015; 785: 119-148. (in Russian).

7. Izmerov NF., Dinisova EN., Kuzmina LP. Biochimicheskie i geneticheskie pokazateli individualnoy chuvstvitelnosti k professionalnim vrednostyam [Biochemical and genetic indices of individual sensitivity to occupational hazards]. Moscow: Tront. 2003; 329-334. (in Russian).

8. Goncharova I A., Freidin M B., Takhauov RM., Karpov AB. Moleculyarnogeneticheskie podhodi ispolzuemie dlya ocenki vliyaniya oblucheniya na genom I individualnuu radiochuvstvitelnost cheloveka [Moleculargenetic approaches used to assess irradiation influence on the genome and individual human radio sensitivity]. Siberian Medical Journal. 2003; 5: 78-83.

\section{ORCID and contributionship:}

Tetyana A. Andrushchenko - 0000-0003-2858-8267 ${ }^{A, D}$

Sergiy V. Goncharov - 0000-0001-7800-0121 ${ }^{B}$

Victor E. Dosenko - 0000-0002-6919-7724 E,F

Konstantin E. Ishhejkin - 0000-0001-7887-0995 E,F

\section{Conflict of interest:}

The Authors declare no conflict of interest

\section{CORRESPONDING AUTHOR Tetyana A. Andrushchenko \\ State Institution „Kundiiev Institute of Occupational Health of the National Academy of Medical Sciences of Ukraine" 75 Saksagansky str, Kijów, Ukraina \\ tel: +380503124814 \\ e-mail: imp-cys@ukr.net}

Received: 18.08 .2019

Accepted: 20.11.2019
A - Work concept and design, B - Data collection and analysis, C - Responsibility for statistical analysis, D-Writing the article, $\mathbf{E}$-Critical review, $\mathbf{F}$ - Final approval of the article 